\title{
A study on existing fisheries management system and the problems faced by the fishers in Loktak lake of Manipur
}

\author{
Nongmaithem Bijaya Lakshmi Devi, Ajit Kumar Ngangbam ${ }^{1}$ and Dr. Sheela \\ Immanuel $^{2}$ \\ ${ }^{I}$ Central Institute of Fisheries Education(CIFE) Fisheries Economics Extension and statistics Division, P.O. \\ Box400061, Mumbai, India \\ ${ }^{2}$ EUMAINE, Ghent university, Belgium, \\ ${ }^{3}$ Principle Scientist, Central Institute of Fisheries Education, P.O-061, Mumbai, India.
}

\begin{abstract}
Fishing is activity which is rarely carried out all alone and is often required management system which has to be formed between people and community. In the present study, five villages around the Loktak lake of Manipur were selected by adopting a case study cum survey method to analyse the fisheries management system existing in the Loktak lake and the problems faced by the fishers in the region during fishing. After catching the fishes, the fishers marketed it immediately to the middlemen either in fresh condition or in processed form as there is no icing facility for storage. Smoking of fishes using the local wood such as Sahi and Kui were found to be the main mode of preservation. Gear and craft mainly operating in the Loktak lake consisted of gill nets and dugout canoes respectively. It was observed that banned seasons are so far does not exist in Loktak lake. Using Rank Based Quotient techniques, the problems of the fishermen were analysed. Strong waves leading to the movement of the phum was reported as the major problem. The construction of Ithai barrage on Loktak lake leads to the reduction in fish productivity.
\end{abstract}

Keywords: barrage, fisheries, gear, management, survey

\section{Introduction}

Fish is an important source of animal protein worldwide which is accounted for 15.7 percent of the global population's intake of animal protein in 2007. Inland fisheries accounted for 2.36 percent of animal protein sources in 2007 (FAO, 2010). India is blessed with huge inland water resources (29,000 kms of rivers, 0.3 million ha of estuaries, 0.19 million ha of backwaters and lagoons, 3.15 million ha of reservoirs, 0.2 million ha of floodplain wetlands and 0.72 million ha of upland lakes). It has been estimated that about 0.8 million tonnes of inland fish is contributed by different types of inland open water systems. The bulk of the production comes from reservoirs and floodplain wetlands, which are managed on the basis of culture-based fisheries. The fourteen major rivers, forty four medium rivers and innumerable small rivers of the country with a combined length of 29,000 kms provide for one of the richest fish faunistic resources of the world (Anon, 2006).

Manipur is one of the hilly landlock region situated in the North Eastern corner of India. Its' fisheries solely consists of inland water fisheries. Inspite of the fact that fishery production of the state is very low which was around 19,200 tonnes/yr (Manipur fisheries department, 2009-2010 report), the demand for fish was found to be very high. In this total fish production figure of Manipur, Loktak lake forms the main contributor of about 60 percent. The commissioning of the Loktak hydroelectric project and the construction of Ithai Barrage however, brought about changes in the fish and fisheries of Loktak lake. Migratory fishes have, since then, disappeared (Singh, 1991a and 1993).

To address all the issues raised on the health of the lake Government of Manipur has set up the Loktak Development Authority (LDA) under "The Manipur Loktak lake (Protection) Act, 2006 (Manipur Act 3 of 2006)" with the objective "to provide for administration, control, protection, improvement, conservation and development of the natural environment of the Loktak lake and for matters connected with as incidental thereto." Inspite of this fact also the development of Loktak lake in term of fisheries management system were not developing still. Therefore, considering the importance of the fisheries in the state and Loktak Lake being the major contributor in the fish production of Manipur, the present study was attempted with the following objectives.

\section{Objectives:}

1) To understand the fisheries management system existing in the Loktak lake region.

2) To study the various problems and suggested solutions from fishers' perspective in the Loktak lake region. 


\subsection{Site description}

\section{Material and methods}

Manipur consists of 90 percent hilly region and largely characterized by the dense forest and inaccessible terrains. According to the land use data, the water bodies of the State occupy about 1.65 percent of the total land coverage and the usable land is 6.66 percent of the total land use pattern of Manipur (Biaklun et. al 2009). Loktak lake which is the largest freshwater lake in Northeast India is located in the southern part of the state. The lake covers an area of about $286 \mathrm{sq} . \mathrm{km}$ at the elevation of $768.5 \mathrm{~m}$ located between longitudes $93^{\circ} 46^{\prime}$ $\& 93^{\circ} 55^{\prime} \mathrm{E}$ and latitudes $24^{\circ} 25^{\prime} \& 24^{\circ} 42^{\prime} \mathrm{N}$ with the direct catchment area of $980 \mathrm{sq} \mathrm{km}$ and indirect catchment of $7157 \mathrm{sq} \mathrm{km}$. (Singh et al, 1994). Fishing activities on the lake mainly consist of traditional type and fishing gears mainly used during the summer season mainly consist of large dip net, rods and pole and line are used. Beside this traps, scooping net, long line and cast net are also used. These additional gears are operated through out the year. In the winter season gill net is mainly used and also phumthaba i.e. the process of the preparation of floating island known as phumdi which act as the fish aggregating device.

\subsection{Selection of villages}

There are nine districts in Manipur and out of these districts Loktak lake comes under two districts namely Bishnupur district and Imphal West district and hence this two districts were selected for the study. The Loktak lake is surrounded by 36 villages. Out of these 36 villages, the five villages were selected for study purpose. They are Moirang which is located in the South of Loktak lake, Thanga is an island in the middle of the Loktak lake, Ningthoukhong in the Northwest of the Loktak lake and Mayang Imphal on the Eastern part of the lake. Keibul Lamjao is a protected area in the Southeastern part of the Loktak lake. These five villages were selected on the basis of large number of fishermen population involving in fishing activities.

\subsection{Selection of the Respondents}

30 respondents from each village such that total 150 respondents were selected from 5 selected villages around the Loktak lake of Manipur for the study through random sampling technique where all the respondents were consisted of male population.

For case study method 2 key informants were selected from each village such that total 10 respondents were selected for the study.

\subsection{Tools for Data Collection}

The datas were collected with structure schedule developed for the study and by taking personal interview of the fishermen. This method was used for the purpose of primary data collection. Data from the fishermen were collected in local language. The secondary data were collected from the published document of the State Fisheries Department and Loktak Development Authority. The data were collected from November 2010 to April 2011. Thus the collected datas were properly tabulated and analysed.

\subsection{Statistical Tools Used}

To draw meaningful conclusion, relevant statistical tool like MS- Excel was used to perform Percentage analysis, mean and standard deviation and Rank Based Quotient.

\section{Rank based quotient (RBQ)}

Rank Based Quotient (RBQ) was used to quantify the data collected by preferential ranking technique by first ranking the parameters and then calculating the Rank Based Quotient (RBQ) given by Sabarathnam (1988), which is as follows:

R.B.Q. $=\frac{\sum \mathrm{fi}(\mathrm{n}+1-\mathrm{i})}{\mathrm{N} \times \mathrm{n}} \quad \mathrm{X} 100$

Where in,

$\mathrm{fi}=$ Number of fishers reporting a particular problem under $\mathrm{i}^{\text {th }}$ rank

$\mathrm{N}=$ number of fishers

$\mathrm{n}=$ number of problems identified

\subsection{Fisheries Management}

\section{Results and discussion}

The livelihood of fishermen inhabited around the Loktak lake were entirely dependent on the fishes caught from the lake. They caught the fishes at anytime from any part of the lake since the Government had not set any limited fishing area for the fishermen. Moreover, there was no leasing system followed in the entire water body of the lake. From the fish landing data of 37 landing centres given in Table- 1 around the Loktak lake of Manipur, it was found out that the landing centres of Thanga area has highest fish catch of about 598.58 
tonnes/yr in Thanga keirang leikai followed by 394.12 tonnes/yr in Thanga chinkha . This may be due to the fact that fishers in this area were frequently availed with the training programmes arranged by the state or central institutes which made them aware of the new technologies developed.

\subsubsection{Market orientation}

The data given in table 2 revealed that nearly 46.67 percent of the fishers marketed the fish through middlemen and existence of commission agents were not found. This may be due to the fact that majority of the fishers did not have time to go to the main market for selling the fishes. The fishers went for fishing in morning and then, after returning they had to segregate the fishes for smoking

and for selling in fresh condition by separating them species wise or size wise. After all these activities, most of them had to give it to the middlemen for sale. For those families having more number of members they used to go to the main market for marketing it.

In pre monsoon season the fish caught in abundance were Catla catla (100 Rs $/ \mathrm{Kg}$ ), Channa striatus (190 Rs /Kg), Colisa fasciatus (180 Rs /Kg) etc. and in monsoon season fishes such as Anabas testudineus (300 $\mathrm{Rs} / \mathrm{Kg}$ ), Notopterus sp. (100 Rs /Kg), Heteropneustes fossilis (300 Rs /Kg) and Monopterus sp. (250 Rs /Kg) were caught in abundance. In post monsoon season, Amblypharyngodon sp. (100 Rs /Kg), Ctenopharyngodon idella $(120 \mathrm{Rs} / \mathrm{Kg})$ and Labeo rohita $(120 \mathrm{Rs} / \mathrm{Kg})$ were caught in abundance. The prices given above were landing centres' prices which will be more as it reaches the main market or other marketing channels.

\subsubsection{Mode of preservation and processing}

After catching the fish, all the fishers go for immediate marketing of the fresh fish and processing of the unspoiled fishes. Since there is no icing facility, storage of the fishes were found to be a big problem for the fishers. Immediate marketing and processing of the fishes were the only options available for them. Method of preservation practiced by the fishers consisted of smoking and fermentation. All (100\%) the respondents were using smoking as the mode of preservation (table 2). Woods such as Sahi and Kui were used for smoking purpose. Sahi wood enhances the colour of the smoked fish whereas Kui wood gives good flavour. Fourteen percent of the fishers also adopted fermentation of fish as the mode of preservation. This may be due to the fact that it requires high initial cost and labour. Therefore only few respondents had adopted it as the mode of preservation.

\subsubsection{Marketing and utilisation of harvested fishes}

Nearly 82.00 percent of the fishers were found using the harvested fish for self consumption as well as marketing (table 2). Out of the total catch they used $0.5 \mathrm{~kg}$ to $1 \mathrm{~kg}$ for their own consumption and the rest of the catch which comes to 6- $20 \mathrm{~kg}$ were marketed. None of the respondents utilized the fishes exclusively for self consumption. This may be due to that fact that they derived their main income for livelihood by marketing the fishes which they caught.

Fishes were carried in tin cans for fresh fish marketing and for smoked fish marketing they used bamboo pots (Fig 4). Marketing channels that were found to exist are:

1. Producer to consumer directly either through main market or local market.

2. Producer to the middlemen called Unja and this Unja again sell the fishes to the consumer either in Bishnupur market or Imphal market (capital city).

\subsection{Method of storage}

Fresh fishes were mainly stored in tin cans which are available in different sizes and the processed fishes were stored in bamboo pots of square shape available in different sizes as per the quantity and the size of the fish. Cost of processing of the smoked fish is very less which are about 3 percent of the total cost and shelf life of the smoked product were in the range of 25-30 days.

\subsection{Information about crafts and gears}

Dugout canoes with single log or double log were mainly operated in the Loktak lake. These canoes were mainly constructed from local wood Uningthou. It was observed that there were no particular operational month, thus fishing activities were operated throughout the year according to the change in the colour of the water that indicates the availability of the fishes. Number of fishermen per trip consists of 2 to 4 based on the size of the boat. Dugout canoes with single log were found to be costlier which is around Rs 18,000-20,000 with an expected life of 30 years whereas dugout canoes with double logs were found to be cheaper which cost Rs 7000-8000 with an expected life of 10 years. Both the canoes cost around Rs. 1500-2000 for annual repair. Canoes were operated once or twice in a day especially in the morning hours and generally landed at noon. Quantity of catch per trip falls around 6-20 Kg/trip. Among the types of fishing gears available, the fishing gears used by the fishers of the Loktak lake consists of gill nets with different mesh size, traps of different sizes and dip nets and scoop nets. 
Gears will said to be selective only for different sizes of fishes but not for species. Gill nets were mainly made from polyethylene fibres and dip nets from nylon and traps were made from bamboo.

From table 3 , it was safely noted that gill nets of different numbers were found to be operated ranging from 13-110 with a mesh size ranging from $13 \mathrm{~mm}-110 \mathrm{~mm}$ available at a price range between Rs. 350 to Rs. 450. The traps used were having the size range from 2-4 ft. with a mesh size of 0.5-1 inches width and 2-4ft. length available at prices ranging from Rs. 50 to 60.

All the respondents were found to have their own gears. Gears such as traps and nets were having an expected life of about 1 year and dip nets were having an expected life of about 5 years provided if it is not affected by the strong winds. Once it is damaged repairing cannot be done but it can be done for cages with the available resources.

\subsubsection{Banned season}

It was observed that banned seasons are so far does not exist in Loktak lake. While taking the suggestion of the fishers regarding the existence of banned season 80 percent were having negative response stating that they do not have any alternative source of livelihood whereas 20 percent had positive response towards it.

\subsubsection{Decreasing of catch}

All (100\%) the fishers had stated that there were sharp decline in the fish catch of Loktak lake with the construction of Ithai barrage. Many of the indigenous species had disappeared since then.

\subsubsection{System of fishing}

All the respondents followed own system of fishing. All the fishers were found to have their own fishing gears and crafts. Some families have large numbers of gears and crafts and some have only few numbers.

\subsubsection{Preference time for fishing}

Fishing activities were mainly carried out during the morning hours as this makes possible for the fishers to market it in the evening time. Moreover, they believed that during morning hours they got more fish catch than in the late hours. In Loktak lake there is no particular fishing ground. The fishers know the availability of the resources from the change in the colour of the water i.e. the availability of the fish food organisms and also the quality of water which is congenial for the fish. Moreover, seasons and monsoons affect the availability of the fishes in the Loktak lake with the evidence that rainy season have more availability of fish. In summer, fishes were mainly caught in plained water bodies and in winter in the macrophytic area. Macrophytes like Eichorrnia and Hydrilla were used to catch the fishes in various traditional ways.

\subsection{Problems Faced During Fishing and Suggested Solutions by the Fishers The $R B Q$ values in table 4 revealed as follow:}

Due to the strong waves, the phums moves here and there that leads to the destruction of various gears and crafts which again results in a huge loss and this was the first major problem given by the fishers (RBQ value 74.77). This may be due to the fact that this problem was faced by majority of the fishers and it affects their daily fishing activities not only financially but also mentally. This could be solved by fixing the phum firmly, as suggested by the respondents.

Due to the wave, phum blocked the way to home of the fishermen when they came back after fishing. This happens mostly in the protected areas. So the boat has to be carried over the phum to bring it back to home which is very difficult. Thus this was reported as second major problem by the fishers (RBQ value 73.86). This may be due to the fact that usually dugout canoes were extremely heavy and it is too heavy to carry along with the loads with goods like fishes that were caught and all the crafts and gears, and pulling it over the phum is a very difficult task for which two or three persons were not enough. Therefore, this is also one of the frequently encountered problems by most of the fishers. This could be solved by preventing the phum movement as suggested by the fishermen.

Since the wind directions were found rushing the phums all over suddenly, the boat along with the fishermen were stucking between two phums leading to the injury and death of the fishermen. Hence it was reported by the fishermen as their third major problem (RBQ value 65.55). This may be due to the fact that losing of life is something that cannot be replaced by anything. Seeing those few incidents as example, the fishers were asking the Government for their security. To prevent this problem from occurring, forest department must take care so that the phum should not move along with the wind by placing something on which the phum will stuck while moving along the wind direction. 


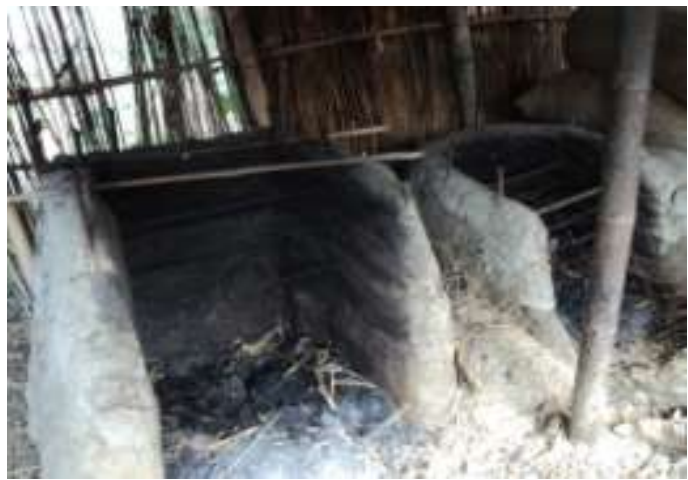

Fig 1. Fish smoking furnace

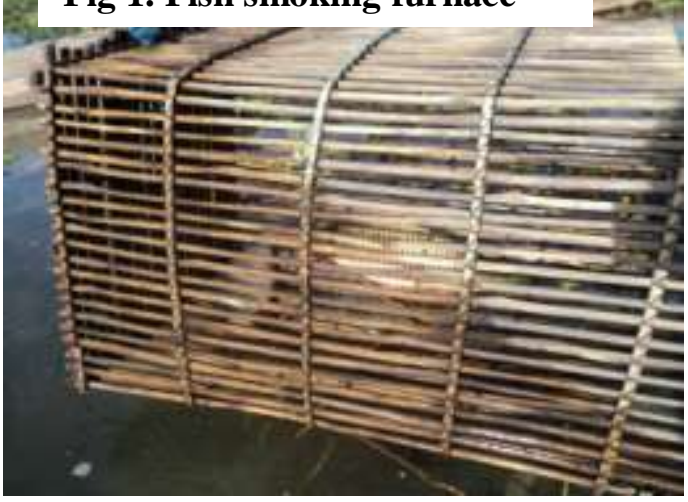

Fig 3. Trapped fish inside the trap



Fig 2. Storing of traps



Fig 4. Fish market (fish place on tin canes and bamboo pots)

Cyclone has also been reported as fourth major problem by the fishermen (RBQ value51.62). This could be solved if the owners of the phum tied their own phum so that destruction will be lesser during cyclone. The construction of Ithai barrage has decreased the fish catch and was also reported as a problem by the fishers (RBQ value 41.59). This could be solved if the department of fisheries regularly released fish seed and people also should stop poisoning of fishes as suggested by the fishermen.

Due to removal of phum, wind speed increases. This was also reported as a problem by the fishers (RBQ value 40.86). So they required bigger boat for fishing. To solve this problem, the fishermen suggested that if the phum is removed, then an alternative station should be there in the middle of the lake so that they can get shelter during strong winds. They also had reported "increase in the number of phum" as a problem (RBQ value 31.46). As the number of phum increases, it is affecting the productivity of the lake.

Some phums should be cleared to solve this problem as suggested by the fishermen.

\section{Conclusions}

From the problems faced by the fishers it can be concluded that the follow has to be taken up as a follow up programme.

$>$ Phum which creates lots of hindrance in the social and economic life of the people should be partially removed and those that remained should be tied properly by the forest department to prevent its movement.

$>$ To ensure sustainability, the Government should developed fisheries management system such as banned season and mesh size regulation for the gears ensuring the alternative livelihood of the fishers.

$>$ The concept of Fisheries co management should be popularised.

Regular awareness programmes on conservation of the ecosystem of the Loktak lake need to be taken up.

$>$ Efforts should be made to prevent pollution and indiscriminate fishing practices.

\section{Acknowledgments}

The authors would like to thank Central Institute of Fisheries Education (CIFE), Mumbai for sponsoring this work. We also thank Dr. Sheela Immanuel for valuable guidance, critical comment and encouragement at every step of this research work. 
Table 1. Fish landing data (2010)

\begin{tabular}{|c|c|c|}
\hline No. & Name of landing centres & Total catch per year(tonnes) \\
\hline 1 & Keincy. & 72.72 \\
\hline 2 & Khoiuman. & 42.336 \\
\hline 3 & Kroasiphai & 54.756 \\
\hline 4 & Dachop & 45.267 \\
\hline 5 & Nolichongkhnllen & 12.6 \\
\hline 6 & T saikh ongaiphai & 19.44 \\
\hline 7 & Trubpl. & 21.6 \\
\hline 8 & Rotsangham & 69.125 \\
\hline 9 & Touppopoi & 123.12 \\
\hline 10 & Thanga khurier leikai & $107 . \overline{6}$ \\
\hline 11 & Thanga pinam leikai & 176.5 \\
\hline 12 & Thanga salam laka & 296.55 \\
\hline 13 & Thanga keirang leikai & 394.12 \\
\hline 14 & Thanga chinkha & 233.49 \\
\hline 15 & Thanga samukhon lika & 91.8 \\
\hline 16 & Thanga keirang leikgi & 598.58 \\
\hline 17 & Phairembam Noirang & 76.368 \\
\hline 18 & Ithing Khurias & 76.788 \\
\hline 19 & Moirang leikai & 50.76 \\
\hline 20 & Khollen leikai. & 24.105 \\
\hline 21 & Sendra likai & 43.36 \\
\hline 22 & khpirom leval & 96.3 \\
\hline 23 & T garam leikai & 75.816 \\
\hline 24 & Ningthoukhong & 19.8 \\
\hline 25 & Keikul ogram & 21.168 \\
\hline 26 & Keiknd makha & 19.788 \\
\hline 27 & Nongmaikheng & 1134 \\
\hline 28 & Khordak mapam & 92.448 \\
\hline 29 & Chingrnei makha & 57.036 \\
\hline 30 & Keibul mamang & 61.56 \\
\hline 31 & I a a sol Takmu & 99 \\
\hline 32 & Karang kachin & 43.992 \\
\hline 33 & Tookpi Khymp & 91.584 \\
\hline 34 & Thinumger mamang & 223.776 \\
\hline 35 & Thinumger anarg & 60.3 \\
\hline 36 & Ningthoukheng kha & 72.576 \\
\hline 37 & Ningthoukhoog mamnang & 34.848 \\
\hline
\end{tabular}

Table.2. Fisheries management

\begin{tabular}{|c|c|c|c|}
\hline Characteristics & Categorv & $\mathrm{N}_{0}$ & Percentage $(06)$ \\
\hline \multirow[t]{3}{*}{ Marketing } & Local market & 40 & 26.67 \\
\hline & Commisgion agent & 0 & $0^{-}$ \\
\hline & Main market & 40 & 26.67 \\
\hline \multirow[t]{2}{*}{ Method of preservation } & Smoking & $150^{-}$ & $100^{\circ}$ \\
\hline & Fementation & 21 & 14 \\
\hline \multirow[t]{3}{*}{ Utilization of the harvested fish } & Self consumption & $\overline{0}$ & $\overline{0}$ \\
\hline & $\begin{array}{l}\text { Self consumption and } \\
\text { marketing }\end{array}$ & $12 \overline{3}^{-}$ & 82 \\
\hline & Only for marketing & 27 & 18 \\
\hline
\end{tabular}


Table 3. Various price list and meh size of different gear

\begin{tabular}{|c|c|c|c|}
\hline Sl. no. & Type of gear & $\begin{array}{l}\text { Price piece } \\
(\mathrm{R})\end{array}$ & Mesh size \\
\hline 1 & Gill nat no. 13 & 350 & $13 \mathrm{~mm}$ \\
\hline 2 & Gill nat no. 15 & 370 & $15 \mathrm{~mm}$ \\
\hline 3 & Gill nat no. 25 & 300 & $25 \mathrm{~mm}$ \\
\hline 4 & Gill nat no. 45 & 300 & $45 \mathrm{~mm}$ \\
\hline 5 & Gill nat no. 65 & 400 & $65 \mathrm{~mm}$ \\
\hline 7 & Gill nat no. 110 & 450 & $110 \mathrm{~mm}$ \\
\hline 8 & Cage 4t. & 50 & 2inchas width, $4 \mathrm{ft}$ legth \\
\hline 9 & Cage $2 \mathrm{~A}$. & 40 & linchas width 2 ft length \\
\hline
\end{tabular}

Table 4 Frequency distribution of $R B Q$ value given by farmers forvarious problem

\begin{tabular}{|c|c|c|}
\hline & & $(n=150)$ \\
\hline PROBLEM & $\mathrm{RBQ}$ & RAMK \\
\hline Strong waves datroy gear: & 74.77 & $\bar{I}$ \\
\hline Phum block the way to home while retuming & 73.86 & II \\
\hline Phum stud the poopla & 65.55 & III \\
\hline Crilona & 51.62 & Tiv \\
\hline Reduce fish catch & 41.59 & \\
\hline Wind sped increase & 40.86 & $\mathrm{ti}$ \\
\hline Incease in phyme reduced ish productivity & 31.46 & $\mathrm{VII}$ \\
\hline
\end{tabular}

\section{References}

[1] FAO, 2010. World review of fisheries and aquaculture. In: The state of world fisheries and aquaculture 2009. FAO, Rome, pp. 3-87.

[2] Anon, 2006. Indian Fisheries Resources and Production. In: Handbook of fisheries and Aquaculture. Published by Indian Council of Agricultural Research, New Delhi, ISBN: 81-7164-061-3: pp.1- 31.

[3] Department of Fisheries, Govt. of Manipur, 2009-2010

[4] H.T. Singh, 1991a. Study on the biology and Culturable Possibilities of the Indegenous fishes of Manipur, Osteobrama belangiri and Monopterus albus Technical Report, ICAR, New Delhi.

[5] H.T. Singh, 1993. Impact of Loktak National Hydroelectric project on the Environment of Manipur. Technical Report, Department of Science, Technology and Environment, Government of Manipur.

[6] P.K. Biaklun, A. Ngangbam, and N. Basavaraja, 2009. Status of aquaculture and fisheries in Manipur. Fishing Chimes, 29(1):102104.

[7] H.T. Singh, and R. K. Singh, 1994. Ramsar sites of India Loktak lake of Manipur. Published by World Wide Fund For Nature, India.

[8] V.E Sabarathanam, 1988. Manuals of Field Experience Training for ARS Scientists. Hyderabad: NAARM. 